\title{
The Acclimation of New Assistant Principals
}

\author{
Hykeem M. Craft \\ Sam Houston State University
}

Julie P. Combs

Sam Houston State University

\author{
Rene Malveaux \\ Sam Houston State University
}

\author{
Sonja A. Lopez \\ Sam Houston State University
}

\begin{abstract}
Although the assistant principal position has been the career path for aspiring principals, some researchers have claimed the position lacks adequacy as a training position. With limited research available, the purpose of this study was to explore the induction and acclimation experiences of newly assigned assistant principals. Following a phenomenological research approach, interviews were conducted with six public school assistant principals. New assistant principals prepared for their positions by seeking prior leadership opportunities and asking questions, but they noted a lack of confidence in making decisions. These new assistant principals, recognizing the importance of professional relationships, worked to build trust with students and teachers. Implications for school district leaders, preparation programs, and aspiring candidates are provided.
\end{abstract}

Keywords: assistant principals, vice-principals, socialization, induction

The role of the school principal has been correlated to student performance and school success (Leithwood, Louis, Anderson, \& Wahlstrom, 2004). Retention of school principals and high numbers of predicted retirements are documented concerns (Battle, 2010). With these predicted vacancies, prepared school leaders will be needed. For many years, the assistant principal position has been the career path for aspiring principals, although some researchers have noted the assistant principal position is not an adequate training position for the principal role (Barnett, Shoho, \& Oleszewski, 2012; Kwan, 2009). Given that assistant principals can be valuable resources for schools and are being trained as future school leaders, more information is needed to support assistant principals in their career transitions. Although a few recent studies have been conducted about the assistant principal (e.g., Petrides, Jimes, \& Karaglani, 2014; Williams, 2012), much of the literature occurred before 1999 (see Oleszewski, Shoho, \& Barnett, 2012). Updated information is needed about the challenges and barriers of newly assigned assistant principals, which can assist current administrators and educators in preparation programs by providing timely and relevant support to these new leaders. As such, the purpose of this study is to explore the induction and acclimation experiences of newly assigned assistant principals.

\section{Review of Literature}

The common duties of assistant principals have changed little over the last four decades (e.g., Hausman, Nebeker, McCreary, \& Donaldson, 2002; Oleszewski et al., 2012; Reed \& Himmler, 1985; Scoggins \& Bishop, 1993). Reed and Himmler (1985) reviewed the literature on assistant principals from 1926 to 1985 and concluded that although studies have been abundant, the "nature of the work has escaped clear conceptualization" (p. 60). Many of these studies addressed similar research questions focused on an analysis of duties using questionnaires (Reed \& Himmler, 1985). Almost a decade later, Scoggins and Bishop (1993) reviewed 26 studies conducted from 1973 to 1992 to identify the most common roles of assistant principals, which were found to be "discipline, attendance, student activities, staff support and evaluation, building supervision, guidance, co-curricular activities, athletics, community agencies, master schedules" (p. 42). Further, the duties of the assistant principal were determined primarily by the principal (Scoggins \& Bishop, 1993). Similarly, Reed and Himmler (1985) concluded the secondary assistant principal was "charged with establishing and maintaining organizational stability" (p. 82), which included developing the master schedule (before the use of 
personal computers), planning the calendar of afterschool activities, and supervising students. In a more recent synthesis of literature about the assistant principal, Oleszewski et al. (2012) affirmed that most of these previously cited duties remain relevant today, with the most cited roles as "student management, instructional leadership, and personnel management" (p. 274). Interestingly, the significance of instructional leadership tasks was not evident until the 2000s (Oleszewski et al., 2012).

Student discipline remains the primary duty of U.S. assistant principals (Hausman et al., 2002; Reed \& Himmler, 1985; Scoggins \& Bishop, 1993). Hausman et al. (2002) observed most of the duties of the assistant principal were centered "around management of people, particularly students" (p. 152), requiring assistant principals to have effective human relations skills. Focused on effective student management, Williams (2012) consulted with experts to create a set of skills and dispositions for secondary assistant principals. She concluded the qualities of effective disciplinarians were honesty, visibility, ethical behavior, fairness, and good communication skills. One of the most commonly cited traits of successful assistant principals was the ability to build and maintain positive relationships, and Williams (2012) noted that building relationships was often linked to building a positive school climate.

Many scholars have indicated the role of the assistant principal is problematic and undefined

(Armstrong, 2012; Petrides et al., 2014). In spite of the "ad hoc task assignments that traditionally accompany the assistant principal role" (Petrides et al., 2014, p. 176), assistant principals participating in Hausman et al.'s (2002) study were positive about their positions. Balancing work and life was a major concern, and assistant principals who worked 55 hours or more a week reported the lowest levels of balance (Hausman et al., 2002). New assistant principals participating in Armstrong's (2014) study described "responsibilities and workloads as physically and emotionally stressful," especially when they "did not have the time, technical skills and the procedural knowledge required to complete everyday managerial and disciplinary tasks" (p. 30). Although some assistant principals wanted to spend more time with instructional tasks (Glanz, 1994; Hausman et al., 2002), their duties as crisis managers outranked "attending to the proactive goals of curriculum planning, instructional supervision, resource allocation, and professional development" (Hausman et al., 2002, p. 152). Armstrong (2012) concluded from a study of 15 new assistant principals the role "remains an underutilized, fragmented, reactive managerial role" (p. 421), and the position should be reconfigured (Armstrong, 2012; Oleszewski et al., 2012).

\section{Preparation for the Position}

The lack of preparation of assistant principals for their positions has been well documented for some years (Hartzell, Williams, \& Nelson, 1995; Hausman et al., 2002). Twenty years ago, Hartzell et al. (1995) concluded new assistant principals did not have the necessary knowledge and skills for their positions and were unaware of the realities of the position and its challenges. One common theme in the literature concerning preparation of assistant principals is the inadequacy of formal preparation programs focused on the role (Armstrong, 2010; Oleszewski et al., 2012). Almost all courses in preparation programs focus on the principal position, with a "disconnect between the relevance of formal training" and the needs of assistant principals (Hausman et al., 2002, p. 152). Assistant principals prepared for their roles on the job through trial and error and with reinforcement from their principals (Mertz, 2006). Further, principals were key in the learning process because they assigned the responsibilities and were in a position to give meaningful feedback (Mertz, 2006). Combined with the lack of pre-service training, Oleszewski et al. (2012) noted few of the professional development opportunities available were specific to the needs of assistant principals.

New assistant principals varied in their levels of teaching experience and knowledge of instructional processes (Hausman et al., 2002). Focused on instructional leader readiness, Searby, Wang, and BrowneFerrigno (2015) surveyed 461 assistant principals from Alabama. Surprisingly, the researchers concluded there was no significant relationship between the readiness for instructional leadership tasks and years of teaching experience or age. The prediction that teachers with more years of classroom experience would be more prepared for instructional leadership was not confirmed in their study (Searby et al., 2015). In contrast, Hausman et al. (2002) noted additional years of teaching experience was related to time spent in instructional leadership among 145 assistant principals from Maine. Specifically, experiences as teacher leaders contributed to new assistant principals' perceived readiness as instructional leaders (Searby et al., 2015). Noted teacher leadership activities were mentoring other teachers, planning or leading professional development, and serving on school and professional development committees (Searby et al., 2015). The researchers explained these leadership roles might might have "exposed them to the 'behind the scenes' 
aspects of building leadership" (Searby et al., 2015, p. 29).

Many researchers have recommended additional professional development and training for assistant principals (Hausman et al., 2002; Oleszewski et al., 2012; Petrides et al., 2014), particularly with the prevalence of "inappropriate professional certification programs" (Armstrong, 2010, p. 709). Noting a specific concern with handling conflict with teachers, Petrides et al. (2014) recommended "increased support to aid them in establishing ongoing constructive conversations with teachers" and ways to establish "nonintrusive processes for impacting teacher practice" ( $\mathrm{p}$. 188). Oleszewski et al. (2012) called for more studies about the professional development needs of assistant principals.

\section{Conceptual Framework}

Theories related to the socialization of assistant principals serve as the conceptual framework of this qualitative study. Career socialization is the process of learning the norms and expectations of a given position. Greenfield (1985) described the socialization process of assistant principals as being informal, random, and varied--a process that differs from that of the principal roles (Armstrong, 2012). Assistant principal training is often on-the-job and informal, random in occurrence, and varied in required acculturation time. In one of the later stages of the socialization process, one's identity changes from that of a teacher to that of an administrator (Greenfield, 1985). Instead of focusing on the stages of socialization, Marshall (1985) focused on the tasks that help the assistant principal assume the new role identity. According to Marshall (1985), initially, the person makes a decision to leave teaching and then learns about the selection process. Next, the new assistant principal experiences the change from teacher to administrator, sometimes described as a culture shock. To adapt to the new role, the assistant principal finds resources and social supports.

Scholars have noted concerns with the socialization process for new assistant principals, referring to the transition as a "trajectory of conflict, resistance, and accommodation" (Armstrong, 2012, p. 418). In a study about the socialization process of 15 new assistant principals, Armstrong (2012) concluded the transition from teacher to administrator is a "complex passage" involving "personal and professional changes" (p. 404) that "destabilize[s] novice VPs cognitively, emotionally, and socially" (p. 418) for which they are unprepared. In a different study, Armstrong (2010) described that new assistant principals were without support at the induction stages and recommended school districts to work together with universities to improve the transition process.

\section{Method}

This qualitative study employed the techniques of phenomenological research methods (Moustakas, 1994). According to Van Manen (1990), a phenomenological design is appropriate to understand the essence of lived experiences of participants. For phenomenological research, Creswell (2013) recommended 3 to 10 participants. Six participants were recruited for the study using snowball sampling techniques, as we used professional contacts to locate participants who served as assistant principals in public schools for at least one year and no more than three years.

A diverse group of participants took part in this study. Four of the participants identified as White and two as Black. Three participants were male, whereas both Black assistant principals were female. All of the participants served fewer than three years in the assistant principal role. Three assistant principals worked at campuses serving students in Grades 6-8, and three worked at campuses serving students in Grades 9-12. Two had been promoted to assistant principal from a teaching assignment on the same campus, and four were placed in a new setting for their first assistant principal assignment.

After consent was given, participants were interviewed in face-to-face settings. The interviews were audio-recorded and transcribed for analysis. Interview questions were developed after a review of the literature and piloted with two assistant principals. The pilot interview results allowed for improvements to data collection. Additional demographic data were collected using questionnaires.

In the transcription analysis, a combination of firstcycle and second-cycle coding techniques was employed (Saldaña, 2013). Initially, applied attribute coding was used for each transcript using the demographic data. Next, first-cycle coding consisting of structural codes was used to organize the large amounts of information gathered from the interviews. Using the structural codes, we searched each transcript, applying a combined descriptive and in-vivo coding. After several rounds of first-cycle coding, clusters of meanings and thematic coding in secondcycle coding were identified.

\section{Results}

To describe the induction and acclimation experiences of newly assigned assistant principals, we pre- 
sent the findings in three structural categories: preparation for the position, challenges of the new assistant principals, and relationships. Themes within each category are described in the following sections. To ensure anonymity, the six participants were assigned the pseudonyms Amy, Bill, Carl, Dalene, Edgar, and Felicia. Summaries are provided in Tables 1, 2, and 3.

\section{Preparation for the Position}

The assistant principals discussed their preparation for the position as a new administrator and the importance of learning about the role. Dalene stated, "You really have to let it be known you are interested, and you have to put in the time to learn." The assistant principals in this study all dedicated many hours to transition to the role of administrator. The three themes used to summarize the new assistant principals' preparation for the position were (a) leadership opportunities, (b) asking questions, and (c) volunteering. Descriptions of each theme are provided in Table 1.

One theme that developed was leadership opportunities, which were the opportunities that assistant principals were afforded before attaining their first administrative position. Amy explained, "I was actually prepared for it [assistant principal position]. And by that I mean I was given the opportunity to serve in multiple roles in my previous district." Felicia also described leadership opportunities as a teacher: "I was a team leader." She added being part of "the flight team" allowed her opportunities to fill in "when administrators were out."

Another common theme to describe the preparation for the assistant principal position was asking questions. All of the assistant principals mentioned the importance of asking questions. Carl shared, "Talking to my dad [an administrator], talking to my uncle [an administrator], and getting some feedback from my high school principal" helped him prepare for the position. Edgar stated, "Don't be afraid to ask questions." The assistant principals shared a spirit of humility and were willing to ask questions to gain a better understanding of the position.

A common theme of volunteering was also present among the assistant principals. Many of the participants mentioned the various aspects of the position and the importance of requesting additional duties as a teacher to be better prepared for the role of administrator. Dalene explained, "You have to take on different responsibilities, saying give me Red Ribbon Week or give me this and let me be in charge." Also, Carl added, "It's like anything, you can tell somebody about it, but until you get your feet wet and do it yourself, you just don't know."

Table 1

Summary of Themes of New Assistant Principals' Preparation

\begin{tabular}{lll}
\hline \multicolumn{1}{c}{ Theme } & Description & \multicolumn{1}{c}{ Significant Statement Example } \\
\hline $\begin{array}{l}\text { Leadership opportuni- } \\
\text { ties }\end{array}$ & $\begin{array}{l}\text { Assistant principals described leadership } \\
\text { opportunities they were given before the } \\
\text { administrative position. }\end{array}$ & $\begin{array}{l}\text { "I was the head volleyball coach which gave me } \\
\text { some leadership experience. I also was then asked } \\
\text { to serve as the department chair for the business } \\
\text { department, and then the opportunity presented } \\
\text { itself for me to be the International Business } \\
\text { Academy Coordinator." }\end{array}$ \\
$\begin{array}{ll}\text { Assistant principals asked questions from } \\
\text { more experienced administrators. }\end{array}$ & $\begin{array}{l}\text { "Asking the current assistant principals I had at } \\
\text { the time, continuously looking at them, question- } \\
\text { ing them how they did certain things." }\end{array}$ \\
$\begin{array}{ll}\text { Assistant principals discussed volunteering } \\
\text { for administrative duties. }\end{array}$ & $\begin{array}{l}\text { "Putting in a lot of hours volunteering especially } \\
\text { because this district and campus is so competi- } \\
\text { tive. I think being pulled in to observe or being } \\
\text { pulled in when administrators were out. I did bus } \\
\text { referrals or tardies." }\end{array}$ \\
& &
\end{tabular}


Journal of School Administration Research and Development

Winter 2016

Table 2

Summary of Themes of Challenges of New Assistant Principals

\begin{tabular}{|c|c|c|}
\hline Theme & Description & Significant Statement Examples \\
\hline Meeting expectations & $\begin{array}{l}\text { Identifying stakeholder needs and re- } \\
\text { quirements }\end{array}$ & $\begin{array}{l}\text { "I think the biggest challenge was learning my way } \\
\text { around, learning who people were, learning what the } \\
\text { kids needed. . . [ [,] and not sure of the expectations } \\
\text { and wanting to do it right." }\end{array}$ \\
\hline $\begin{array}{l}\text { Possessing confidence } \\
\text { in decision making }\end{array}$ & $\begin{array}{l}\text { Feeling self-assured in performing } \\
\text { daily tasks }\end{array}$ & $\begin{array}{l}\text { "Having to adjust from a teacher mindset to an admin- } \\
\text { istrator mindset. As a leader, I've got to be more de- } \\
\text { cisive in my actions and not defer to someone else." }\end{array}$ \\
\hline $\begin{array}{l}\text { Unpredictability of the } \\
\text { job }\end{array}$ & $\begin{array}{l}\text { Managing the sporadic nature of the } \\
\text { day's work with constant interruptions }\end{array}$ & $\begin{array}{l}\text { "You realize there is no schedule, and you can't pen- } \\
\text { cil things in because everybody's interruption is } \\
\text { something and you have to stop and deal with that." }\end{array}$ \\
\hline Evaluating teachers & $\begin{array}{l}\text { Conducting teacher evaluations and } \\
\text { providing feedback }\end{array}$ & $\begin{array}{l}\text { "I think my biggest challenge especially my first year } \\
\text { is going into and really actually evaluating teachers on } \\
\text { subjects that I'm not strong in, and then trying to give } \\
\text { them helpful advice on how to make it better." }\end{array}$ \\
\hline $\begin{array}{l}\text { Time management/ } \\
\text { organization }\end{array}$ & $\begin{array}{l}\text { Managing time for efficiency and creat- } \\
\text { ing systems to produce effectiveness }\end{array}$ & $\begin{array}{l}\text { "Learning to manage everything; it's a lot to manage. } \\
\text { It's an overwhelmingly large amount of work to man- } \\
\text { age from just having a system of returning calls, } \\
\text { checking in with teachers, following up with kids, } \\
\text { communicating with parents, and being responsible } \\
\text { to my principal." }\end{array}$ \\
\hline
\end{tabular}

\section{Challenges of New Assistant Principals}

Each assistant principal articulated numerous challenges faced during their beginning years in the administrative position. Transitioning into a leadership role of teachers and managing all of the unexpected and unplanned crises were difficulties repeatedly mentioned by the participants. For example, Amy explained her biggest transition was "not being in control of the day." Taking on a role where the landscape of the position changed daily was another challenge expressed by the assistant principals. The five themes used to summarize the challenges faced by the new assistant principals were (a) meeting expectations, (b) possessing confidence in decision making, (c) unpredictability of the job, (d) evaluating teachers, and (e) time management/organization. Descriptions of each theme are provided in Table 2.
One theme that developed was the assistant principals' challenge of meeting expectations. Identifying the needs of the various campus stakeholders and fulfilling the requirements of the multitude of duties and responsibilities were often mentioned. Amy recounted the difficulty in being a new administrator at an unfamiliar campus and the challenges of meeting expectations:

I didn't know what I was walking into; I didn't know any of the people on the campus. I didn't know much about the dynamics of the students, the faculty, or the staff on the campus. The biggest challenge was learning my way around, learning who people were, and learning what the kids needed.

Carl, also new to his middle school campus, is in his first year as an assistant principal and remembered his concerns about meeting expectations of his new peer 
group: "Everything was brand new. I knew nothing at all and did not know what to expect."

Another emerging theme was possessing confidence in decision making. The assistant principals struggled with feeling self-assured in their new roles and in making administrative decisions. Bill reflected, "I remember when I first started that fear of 'oh, what if I do things wrong?'" His hopes for the first year were to "not screw up." In addition to dealing with learning the expectations required of her, Amy expressed concerns about her abilities. She was worried about "not knowing ... or having enough confidence in myself that I had all the tools to do that [lead a school]."

A common theme of unpredictability of the job was also present among the new campus administrators. Many of the participants mentioned some aspect of the ever-changing daily routine of the assistant principal's role and how a well-planned day could easily be thwarted by an unexpected event. Carl realized, "I'm not in control anymore. I don't have my little bubble anymore." Edgar further noted the irregularity of the position as a challenge:

This job is unbelievably unpredictable. So, to set a schedule out for yourself for a week, or even a day, like today, I'm going to do this, and you do it naturally as organized people do, but [you] never do[;] . .. never does it work out like you want it to.

Also, the less experienced assistant principals struggled in their first year to conduct classroom observations and provide valuable feedback to their teachers. The theme of evaluating teachers emerged from the interviews. Carl described "the need for time with your group of assistant principals in the district and talk about how something [observations] would be scored" to aid with conducting teacher observations.

Last, the theme of time management/organization was a commonality among the assistant principals. Finding a way to complete all the tasks in a timely, efficient manner, especially with the aforementioned unpredictability of the job, was also a challenge. Bill commented on the challenge of time management:

Knowing how much time I needed to put into different aspects of walk-throughs, investigations, discussing situations with students, and giving time to teachers, making sure everyone is doing what they are supposed to and really trying to get all of your reports and everything done on time.

Felicia concurred she was challenged with "learning to manage everything. . . . It was a lot to learn to manage, so getting organized and getting a system was the biggest challenge."

\section{Relationships of the New Assistant Principals}

The assistant principals described their relationships as being in transition as they adjusted to their roles as administrators. For example, Felicia described her biggest challenge as adjusting "from a teacher mindset to an administrator mindset." The assistant principals in this study all experienced a transition in their friendships when changing roles from teacher to assistant principal. They had few friendships, and those they had were not part of their workplace. Instead, at their jobs they focused on the professional relationships they were building with teachers. Three themes were used to summarize the relationships of these new assistant principals. These new administrators were trust builders and conflict managers with distanced friendships. A description of each theme is shown in Table 3.

As trust builders, the assistant principals discussed the strategies they used to build trust and the development of their relationships with teachers over time. Edgar described his strategy:

My goal really every day is to say hello to every one of my teachers I see in the hallway[,] . . . so if we can build them up enough to know we care about them, um, it's easier to have that tough conversation.

The development of trust was also noted when participants described a success story; all six assistant principals mentioned their positive relationships with teachers or students as one of their successes. Carl described his success with two teachers: "The relationship between us continued to strengthen." He believed the teachers were able "to do a better job in the classroom" because of their supportive relationship.

Another common theme to describe the relationships of the new assistant principals was conflict managers. Five of the assistant principals talked about their challenges with addressing conflict with teachers. Bill described the transition from teacher to administrator:

You're worried about stepping on people's toes or hurting people's feelings, and I think for me, that was the biggest change.... [,] and typically as a teacher, you avoid uncomfortable situations, and you can get away from them. But as a principal, those you kind of live with.

Carl also described his difficulty in addressing teachers with concerns. He shared, "If they [teachers] mess 
Table 3

Summary of Themes of Challenges of New Assistant Principals

\begin{tabular}{|c|c|c|}
\hline Theme & Description & Significant Statement Example \\
\hline Trust builders & $\begin{array}{l}\text { Assistant principals discussed the develop- } \\
\text { ment of relationships with the teachers they } \\
\text { supervised over time. }\end{array}$ & $\begin{array}{l}\text { "Building that trust and working with teachers } \\
\text { would probably be the biggest success[;] . . . they } \\
\text { understand that we're there to help them." }\end{array}$ \\
\hline Conflict managers & $\begin{array}{l}\text { Assistant principals adjusted to the role ex- } \\
\text { pectation of addressing problems with } \\
\text { teachers they supervised. }\end{array}$ & $\begin{array}{l}\text { "It was harder for me when I had to go correct } \\
\text { somebody because there was that knot in my stom- } \\
\text { ach because I had to put friendship on the line, a } \\
\text { friendship and comradery I had built up as teach- } \\
\text { ers." }\end{array}$ \\
\hline $\begin{array}{l}\text { Distanced friend- } \\
\text { ships }\end{array}$ & $\begin{array}{l}\text { Assistant principals, in their roles as super- } \\
\text { visors, described their friendships as ac- } \\
\text { quaintances. }\end{array}$ & $\begin{array}{l}\text { "As AP my first time around, I felt like it was lonely } \\
\text { at the top }[;] \text {. . . it was different switching into a role } \\
\text { where people stayed away from me just because of } \\
\text { my title." }\end{array}$ \\
\hline
\end{tabular}

up, you have to call them on it." His challenge was "knowing how to do that ... in a professional way ... to keep them motivated to work and to keep that respect." Dalene concluded, "Some people took it [correction] really well; others, it crawled all over them," and some "people just don't want to be corrected."

Another theme describing relationships was distanced friendships. All of the assistant principals talked about changes in friendships at work, which they accepted as part of their new roles as administrators. Both Carl and Felicia used the phrase "it's lonely at the top" to describe their changed social positions in their schools. Bill explained that in his role as an administrator, "You don't usually have really friends, [rather] more acquaintances," and the "friendship part kind of gets a little tricky [when] you have to look at them and tell them they are doing something wrong." Commenting on her exclusion from social events with teachers, Dalene explained, "I'm not invited to the social gatherings like I used to be. And it's not because the friendship isn't there, it's just teachers can't vent."

Of the assistant principals in this study, two became administrators in the same schools that they were teachers and four were in different schools. Although all of the assistant principals reported a change in their friendships as they transitioned from teachers to administrators, some differences were noted in these two groups. The individuals in unfamiliar settings seemed to experience less difficulty with friendships and their new role. Amy shared, "I started on a new campus, in a new district, and so my role is what it was, and I didn't have friends already to have to adjust." In contrast, Dalene worked in the same school as a teacher and administrator. She explained being in the same school was "easier for me because I had relationships with the staff, and I feel like I had a lot of support." At the same time, she noted, "It was harder for me when I had to go correct somebody because there was that knot in my stomach because I had to put friendship on the line."

\section{Discussion}

A consistent finding in our study was new assistant principals prepared for their positions by seeking leadership opportunities, asking questions, and volunteering - activities which have also been noted by Mertz (2006). Participants benefitted from prior leadership positions (e.g., department heads, team leaders, and coaches), confirming the work of other researchers (Hausman et al., 2002; Searby et al., 2015). Also, these new assistant principals sought out informal mentorships from their peer administrators, understanding the importance of asking questions in their new roles. As confirmed in the literature (e.g., Mertz, 2006; Oleszewski et al., 2012), even after completing master's degrees, obtaining state certifications, and securing their first campus administrative positions, many new assistant principals in our study did not possess the confidence to make decisions in their new roles.

The many challenges that surfaced during the participants' beginning years as assistant principals were meeting others' expectations, handling the job unpredictability, evaluating teachers, and managing time. 
Although some of the participants expressed difficulty in knowing what was expected of them by their new peers (especially at a new school), others doubted their self-efficacy in taking action. Some respondents addressed the challenges in adjusting from a teacher role with a structured, daily routine to an administrator role, which lacked structure and routine. Greenfield (1985) and Marshall (1985), who provided early theories about the socialization process of new assistant principals, also noted these concerns. More recently, Armstrong (2015) characterized the assistant principal position as having "hectic and fragmented working environments where challenge and change are the norms" (p. 110). The assistant principals in our study attempted to cope with these challenges using time management strategies; however, we predict the nature of the position will continue to offer repeated challenges for these novice administrators

(Armstrong, 2010, 2012).

Similar to prior studies about assistant principal transition (Armstrong, 2012; Greenfield, 1985), participants in this study witnessed changes in their relationships during their transitions. Focusing on the importance of building trust with teachers, parents, and students, new administrators offered positive relationships as a way to manage ongoing conflicts inherent in their new roles. Concurring with Hausman et al. (2002) and Williams (2012), we noted that these assistant principals had to build positive relationships and manage many conflicts - skills for which they were sometimes unprepared.

\section{Implications and Recommendations}

Based on the findings from the study, instructors of principal preparation programs can assist in the preparation and transition of new leaders. All leadership candidates need time to reflect upon and develop their relationship-building and conflict-management skills. Some participants commented that as teachers, they could avoid conflict-filled situations that were unavoidable as administrators. Specific exercises and case studies designed to help candidates assimilate and practice decision-making skills might be helpful.

Aspiring candidates need a more realistic view of the roles and responsibilities of the administrator. Both preparation programs and school district mentors can assist in the communication of accurate job descriptions, work conditions, and roles. Educators who have accepted jobs with an accurate job preview have been more likely to remain employed and experience higher job satisfaction levels (Ellis, 2014).
After new assistant principals have been hired, school districts help them in understanding their roles as trust builders and conflict managers. From our study, we noted participants voiced many challenges in their transitions from teachers to administrators. School district leaders should provide a support network composed of experienced administrators to help new assistant principals manage the professional loneliness they experience as new administrators. The respondents specifically requested school district leaders be more intentional with support, providing collaboration opportunities and interactive, hands-on professional development. For example, Felicia shared, "They [the individual districts] need to have a system in place to support APs--a system of professional development, a system of go-to people, a system of protocols and procedures that APs should follow."

Amy and Edgar discussed the need for districts to have better mentoring programs to support new assistant principals allowing collaboration among the new administrators. Similarly, Bill and Carl discussed providing support to new assistant principals in the areas of basic policies and procedures and new information from the state, but with the hands-on approach of role-playing. Bill recommended "more roleplaying ... [and] coaching them [new assistant principals] through it. [For example,] if you do expel a kid or send them to an alternative campus ... OK, what do you do then?" He expressed that many first-year assistant principals don't know certain protocols. Carl concluded, "Give them the handbook; let them experience it. [Trainings on] discipline and real-life scenari$\mathrm{os}[$,$] ... giving actual attendance issues and having$ me go through the court scenario[,] . . teacher appraisals[,] and how to give proper feedback." These needs were also noted in previous studies (Hausman et al., 2002; Oleszewski et al., 2012; Petrides et al., 2014).

Based on the study's findings, there are several implications for assistant principals as they transition into the role. First, new assistant principals should be prepared for the transition into their new role by acknowledging the potential of distanced friendships, increased conflict, and unstructured work environments. New assistant principals might benefit from observing effective administrators handle conflict, build relationships, and manage the tasks of the position. A consistent finding among the respondents in this study was the importance of preparing early by learning the logistics of the organization as soon as possible. For example, one of the participants, Amy, discussed the importance of showing initiative and 
being proactive in getting to know the job expectations, the building, and the culture quickly. Having this knowledge could facilitate introductions with students and teachers, possibly making it easier to develop a rapport with them and to feel connected within the building.

Another consistent finding was being teachable and seeking advice. Many of the participants were of the opinion that if a situation arises in which a new assistant principal does not know the answer, then he or she should simply seek out advice. Some of the participants also recommended new assistant principals be willing to open to try new ideas and absorb as much information as possible - being teachable. Bill advised, "Breathe[;] . . . all you can do is the best you can. Don't be afraid to ask. ... [and] learn to manipulate your time." Carl described the importance of flexibility, remarking, "You have to be willing to change it up. Be open, don't be prideful, and know there are going to be some gray areas." Dalene, Edgar, and Felicia discussed the relevance of seeking others who have either previously served in the assistant principal role or who are currently serving in the role and have done so successfully for some time. Dalene shared, "With their [others in the profession] experience, they have a different outlook. ... As a new assistant principal, you may still see it [the duties of the job] as a teacher." Edgar advised to "buddy with them [seasoned administrators]. . . . Mentor with them. ... Really ask questions." Felicia advised new assistant principals to "talk to people and get a different perspective, and then find your own way. Don't be too hard on yourself." Learning the logistics of the organization, being teachable, and seeking advice were all important actions recommended to take in the first few months on the job.

\section{Conclusion}

School leaders are instrumental in the education of students (Branch, Hanushek, \& Rivkin, 2012; Coelli \& Green, 2012; Grissom, Kalogrides, \& Loeb, 2015). Because a majority of school principals were once assistant principals, the position of the assistant principal is viewed as a training position. However, a need for more information about this position remains, as the literature is dated (before 1999) and scant. Our study was an attempt to add more recent information about the induction and acclimation experiences of newly assigned assistant principals. Although data saturation was reached for the research questions posed, limitations were present such that we recommend future researchers include more voices of beginning administrators. As described in the research litera- ture, the professional relationships of assistant principals changed as they transitioned from teacher to administrator. Although most of the participants seemed to accept the reduced social interaction at work, they acknowledged the need to build positive relationships with teachers and students to manage the increased conflicts inherent in their positions.

\section{References}

Armstrong, D. (2010). Rites of passage: Coercion, compliance, and complicity in the socialization of new vice-principals. Teachers College Record, 112(3), 685-722.

Armstrong, D. (2012). Connecting personal change and organizational passage in the transition from teacher to vice principal. Journal of School Leadership, 22, 398-425.

Armstrong, D. (2014, April). Transition to the role of principal and viceprincipal study. Retrieved from https:/ / educationleadership-ontario.ca

Armstrong, D. (2015). Listening to voices at the educational frontline: New administrators' experiences of the transition from teacher to vice-principal. Brock Education Journal, 24 (2), 109-122.

Barnett, B. G., Shoho, A. R., \& Oleszewski, A. (2012). The job realities of beginning and experienced assistant principals. Leadership and Policy in Schools, 11(1), 92-128.

Battle, D. (2010). Principal attrition and mobility: Results from the 200809 principal follow-up survey (NCES 2010-337). Retrieved from http:/ /nces.ed.gov/pubs2010/2010337.pdf

Branch, G., Hanushek, E., \& Rivkin, S. (2012). Estimating the effect of leaders on public sector productivity: The case of school principals (NBER Working Paper No. 17803). Retrieved from http://www.nber.org/papers/w17803.pdf

Coelli, M., \& Green, D. (2012). Leadership effects: School principals and student outcomes. Economics of Education Review, 31 (1), 92-109.

Creswell, J. W. (2013). Qualitative inquiry \& research design: Choosing among the five approaches. Thousand Oaks, CA: Sage.

Ellis, C. L. (2014). From hiring process to retention: The relationship among accurate job previews, position fit, teacher satisfaction, and retention (Doctoral dissertation). Retrieved from ProQuest Dissertations and Theses database. (Order No. 3581899)

Glanz, J. (1994). Redefining the roles and responsibilities of assistant principals. Clearing House, 7(5), 283-287.

Greenfield, W. (1985). The moral socialization of school administrators: Informal role learning outcomes. Educational Administration Quarterly, 21, 99-119.

Grissom, J., Kalogrides, D., \& Loeb, S. (2015). Using student test scores to measure principal performance. Educational Evaluation and Policy Analysis, 37(1), 3-28.

Hartzell, G. N., Williams, R. C., \& Nelson, K. T. (1995). New voices in the field: The work lives of first-year assistant principals. Thousand Oaks, CA: Corwin Press. 
Hausman, C., Nebeker, A., McCreary, J., \& Donaldson, G. J. (2002). The worklife of the assistant principal. Journal of Educational Administration, 40(2), 136-157. doi: $10.1108 / 09578230210421105$

Kwan, P. (2009). The vice-principal experience as a preparation for the principalship. Journal of Educational Administration, 47 (2), 191-205. doi: 10.1108/09578230910941048

Leithwood, K., Louis, K. S., Anderson, S., \& Wahlstrom, K. (2004). How leadership influences student learning. New York, NY: The Wallace Foundation. Retrieved from http:// www.wallacefoundation.org

Marshall, C. (1985). Professional shock: The enculturation of the assistant principal. Education and Urban Society, 18(1), 2858.

Mertz, N. (2006). The organizational socialization of assistant principals. Journal of School Leadership, 16, 644-675.

Moustakas, C. E. (1994). Phenomenological research methods. Thousand Oaks, CA: Sage.

Oleszewski, A., Shoho, A., \& Barnett, B. (2012). The development of assistant principals: A literature review. Journal of Educational Administration, 50, 264-286. doi: $10.1108 / 09578231211223301$

Petrides, L., Jimes, C., \& Karaglani, A. (2014). Assistant principal leadership development: A narrative capture study. Journal of Educational Administration, 52, 173-192. doi:10.1108/ JEA-01-2012-0017

Reed, D. B., \& Himmler, A. H. (1985). The work of the secondary assistant principalship: A field study. Education and Urban Society, 18(1), 59-84.

Saldaña, J. (2013). The coding manual for qualitative researchers. Thousand Oaks, CA: Sage.

Scoggins, A., \& Bishop, H. L. (1993, Nov). A review of the literature regarding the roles and responsibilities of assistant principals. Paper presented at the MidSouth Educational Research Association, New Orleans, LA.

Searby, L., Wang, C.-H., \& Browne-Ferrigno, T. (2015). The profile of the ready assistant principal. Retrieved from http:/ / ncpeaprofessor.org/wp-content/uploads/2015/10/ Conference-Program.pdf

Van Manen, M. (1990). Researching lived experience: Human science for an action sensitive pedagogy. New York, NY: State University of New York Press.Williams, S. (2012). Examination of the skills and dispositions needed for assistant principals to be effective disciplinarians: Having the "right stuff" as assistant principal. Michigan Academician, 41, 92-112. Retrieved from http://journal.themichiganacademy.org/ doi/abs/10.7245/0026-2005-41.1.92 